\title{
Hubungan Kontrol Diri dan Harga Diri terhadap Kecenderungan Narsistik pada Mahasiswa Semester Awal Pengguna Instagram
}

\author{
Aulia Nur Laeli \\ Eka Sartika \\ Furqan Nugraha Rahman \\ Rifka Fatchurrahmi \\ Program Studi Magister Psikologi Profesi \\ Program Pascasarjana Universitas Ahmad Dahlan, Yogyakarta
}

\begin{abstract}
This study aims to determine relationship between self-control and self-esteem with a narcissistic tendency in the first semester students on instagram users. Subjects were students of the Faculty of Psychology second grade with characteristics aged 18-21 years, using social media instagram and upload photos or videos as much as more than 5 times a day. The results were analyzed using regression multiple analysis. Based on result of data analysis were correlation coefficient between self-control variable and self-esteem with narcissistic tendency score $R=0.535$, with significance value equal to $\mathrm{p}=0.000(\mathrm{p}<0.01)$, and $\mathrm{F}$ value count on anova table equal to 10.040 ( $F$ count $>\mathrm{F}$ table $=4.74)$. The effective contribution of self-control and self-esteem to the narcissistic tendency of $28.7 \%$, while the remaining $71.3 \%$ is influenced by other variables. There is a negative relationship between self-control and self-esteem with the tendency of narcissistic in the first semester students instagram users. The higher the self-control and self-esteem the lower the narcissistic tendency.
\end{abstract}

Keywords: college students, instagram, narcissistic tendencies, self-control, self-esteem

\begin{abstract}
Abstrak. Penelitian ini bertujuan untuk menguji apakah ada hubungan antara kontrol diri dan harga diri dengan kecenderungan narsistik pada mahasiswa semester awal pengguna instagram. Subjek yang digunakan dalam penelitian ini adalah mahasiswa Fakultas Psikologi angkatan semester 2 dengan kriteria berusia 18-21 tahun, menggunakan media sosial instagram dan mengunggah foto atau video sebanyak > 5 kali dalam sehari. Analisis yang digunakan ialah regresi berganda. Hasil koefisien korelasi antara variabel kontrol diri dan harga diri dengan kecenderungan narsistik diperoleh skor $\mathrm{R}=0.535$, dengan nilai signifikansi sebesar $p=0.000(p<0.01)$, serta nilai $\mathrm{F}$ hitung pada tabel anova sebesar 10.040 (F hitung $>$ F tabel $=4.74$ ). Sumbangan efektif kontrol diri dan harga diri terhadap kecenderungan narsistik sebesar $28.7 \%$, sedangkan sisanya $71.3 \%$ dipengaruhi oleh variabel lain. Berdasarkan hasil penelitian dapat ditarik kesimpulan bahwa ada hubungan negatif antara kontrol diri dan harga diri secara simultan dengan kecenderungan narsistik pada mahasiswa semester awal pengguna instagram. Semakin tinggi kontrol diri dan harga diri maka semakin rendah kecenderungan narsisitik.
\end{abstract}

Kata Kunci: harga diri, instagram, kecenderungan narsistik, kontrol diri, mahasiswa

Internet menyediakan media yang memberikan kemudahan pengguna mempresentasikan diri, saling berinteraksi dalam waktu singkat dan tanpa terbatas jarak. Media ini disebut sebagai jejaring sosial. Jejaring sosial yang sering digunakan saat ini

Korespondensi: Aulia Nur Laeli. Email: aulianurlaeli@gmail.com 
adalah Instagram. Berdasarkan hasil survey yang dilakukan oleh We are Social ditemukan bahwa Instagram menjadi media sosial yang berada pada peringkat ketiga yang paling banyak digunakan di Indonesia (Suryanto, Puteri \& Pratama, 2019). Selain itu, menurut data Asosiasi Penyelenggara Jasa Internet Indonesia (2016), pengguna instagram sekitar $82.6 \%$ dan berada pada peringkat teratas, sedangkan sisanya ialah pengguna Facebook (66.5\%) dan Path (49.6\%).

Suryanto (2010) menyebutkan bahwa salah satu pengguna internet adalah mahasiswa. Mahasiswa lebih rentan untuk menjadi pecandu internet karena kesibukan dan aktifitas yang banyak dari mahasiswa, membuat mahasiswa bergantung pada internet. Salah satu media internet yang sering digunakan adalah jejaring sosial, khususnya instagram. Mahasiswa mengunggah foto selfie atau video yang menarik tentang dirinya dengan disertai status yang sifatnya memperkuat karakter foto yang diunggah. Biasanya membuat status menarik agar dapat memikat pengguna lain untuk memberikan komentar positif atau tanda love. Mengunggah foto atau video dengan intensitas yang semakin sering akan mengganggu tercapainya perkembangan diri yang optimal. Mahasiswa akan mengalami kecenderungan untuk mengunggah foto atau video demi mendapatkan perhatian dari orang lain. Tindakan tersebut menunjukkan perilaku yang mengarah pada kepribadian narsistik (Weiser, 2015).

Menurut American Psychiatric Association dalam DSM V (2013), kecenderungan kepribadian narsistik adalah suatu pola kepribadian yang menetap ditandai dengan adanya fantasi atau perilaku berlebihan terhadap kesuksesan, kekuatan, kecerdasan, kecantikan, dan cinta ideal, kebutuhan besar untuk dikagumi oleh orang lain serta kurangnya kemampuan untuk berempati. Ciri-ciri kecenderungan kepribadian narsistik menurut The Diagnostic Statistical and Manual Mental Disorder V (DSM V) dari American Psychology Association (2013), dimulai pada masa remaja, dewasa awal, hingga masa dewasa dan tampak dalam berbagai konteks, seperti yang ditunjukkan beberapa aspek berikut ini, Perasaan hebat bahwa dirinya adalah individu yang penting: Memiliki perasaan hebat bahwa dirinya adalah individu yang penting (misalnya: membesar-besarkan bakat dan prestasi yang dimiliki, berharap diakui sebagai individu yang superior tanpa disertai dengan prestasi yang sepadan). Artinya bahwa individu yang mengalami gangguan kepribadian narsistik memiliki keyakinan atas kemampuan diri yang berlebihan, memiliki sifat egois yaitu mengutamakan kepentingan pribadi serta memiliki perasaan superioritas (berkuasa).

Asik dengan fantasi tanpa batas tentang kesuksessan, kekuatan, kecerdasan, kecantikan, atau cinta ideal. Artinya bahwa 
individu dengan gangguan kepribadian ini memiliki pemikiran yang terpaku pada khayalan akan apa yang ada didirinya dan keberhasilan yang diraihnya. Keyakinan bahwa dirinya "istimewa". Mereka merasa hanya dipahami oleh orang yang istimewa, atau seharusnya hanya berhubungan dengan orang-orang istimewa lain atau orang-orang yang berstatus tinggi. Keyakinan bahwa dirinya merupakan individu yang "Istimewa dan Unik" sehingga hanya dapat dipahami atau seharusnya hanya berhubungan dengan orang-orang yang spesial atau yang memiliki kedudukan yang tinggi. Artinya individu dengan kepribadian ini merasa bahwa dirinya berbeda dari individu yang lain, sehingga individu memiliki keyakinan bahwa dirinya hanya dapat berteman dengan orang yang sepadan dengannya. Mengeksploitasi orang lain untuk mencapai tujuannya. Mereka sanggup mengambil keuntungan dari orang lain demi menambah kekuasaannya dan menuntut orang lain memenuhi keinginannya walaupun orang lain harus mengorbankan kebutuhannya.

Kebutuhan yang berlebih untuk dikagumi, dipuja, serta diperhatikan. Artinya bahwa individu dengan kepribadian ini memiliki keinginan untuk menjadi pusat perhatian. Sering iri terhadap orang lain atau percaya bahwa orang lain iri kepadanya. Mereka merasa orang lain selalu iri atas kesuksesan dirinya sehingga menyebabkan hubungan mereka dengan lingkungannya cenderung dangkal, karena tidak dapat menjalin hubungan timbal balik yang seimbang dengan orang lain. Memiliki perasaan bernama besar yaitu harapan yang tidak masuk akal akan perlakukan khusus. Menuntut untuk dipenuhi secara otomatis dan sesuai dengan harapannya. Eksploitatif secara interpersonal, yaitu dengan mengambil keuntungan dari orang lain untuk mencapai tujuannya sendiri. Artinya bahwa individu dengan kepribadian ini akan memanfaatkan kemampuan orang lain untuk kepentingan pribadi.

Kurang memiliki empati, tidak mau mengenali atau mengetahui perasaan serta kebutuhan orang lain. Artinya bahwa individu dengan kepribadian narsistik cenderung memiliki kepedulian yang rendah antar individu. Memiliki perasaan iri terhadap orang lain, atau percaya bahwa orang lain iri terhadap dirinya. Artinya bahwa individu dengan kepribadian ini memiliki perasaan cemburu yang berlebih kepada orang lain atau merasa bahwa orang lain cemburu atau iri terhadap dirinya. Menunjukkan perilaku sombong / angkuh. Artinya bahwa individu dengan kepribadian ini menunjukkan perilaku yang merendahkan atau meremehkan orang lain, serta senang memperlihatkan barang yang dimiliki (pamer) kepada orang lain.

Menurut Wiramihardja (2015) kepribadian narsistik adalah berusaha menjadi tampil agung, menamakan dirinya 
dengan gambaran besar. Mereka tenggelam dalam keasyikan (preoccupation) menerima atensi, salah dalam menerima reaksi orangorang sekitarnya, self-promotion dan lack of emphaty (kurang mampu memahami dan memiliki perasaan orang lain). Selain itu, kepribadian narsistik merupakan pola yang telah lama menetap (long-standing pattern) yang menyangkut perilaku, pikiran, dan perasaan yang sangat maladaptif (highly maladaptive) bagi individu maupun orangorang disekitarnya yang sudah ada sejak masa remaja atau dewasa awal hingga masuk masa dewasa.

Widianti (2013) mengungkapkan dalam penelitian-penelitian terdahulu, orang-orang bersifat narsis cenderung tidak disukai oleh orang-orang yang mengenalnya. Ojanen, Findley, dan Fuller (2012) dalam penelitiannya juga menyatakan adanya hubungan antara narsisme, temperamen, agresi fisik, dan agresi relasional antar teman sebaya pada remaja. Narsisme memicu munculnya perilaku agresi fisik pada laki-laki, serta agresi fisik dan relasional pada laki-laki dan perempuan. Remaja dengan kepribadian narsistik juga mengalami kesulitan untuk menerima kritik dari orang lain, dan selalu beranggapan bahwa dirinya istimewa. Remaja yang berkepribadian narsistik juga mempunyai anggapan bahwa dirinya spesial, ambisius, dan suka mencari ketenaran (Safitri, 2011).

Selain itu remaja dengan kepribadian narsistik akan bertindak secara berlebihan demi mencari ketakjuban dari orang lain. Tindakan secara berlebihan ini merupakan suatu tindakan yang dilakukan oleh remaja dengan cara yang berbeda dari masyarakat pada umumnya. Remaja dengan kepribadian narsistik akan terobsesi untuk menunjukkan kehebatan serta pesona diri dengan melakukan hal-hal yang unik dan berbeda dibandingkan dengan orang lain. Hal ini dapat dilihat dari bagaimana remaja tersebut menuangkan obsesinya melalui foto diri. Salah satu fenomena yang terjadi di kalangan masyarakat yaitu remaja narsis di kebun bunga amaryllis, daerah Gunung Kidul, Yogyakarta. Reska K. Nistanto (kompas.com) menyatakan bahwa keindahan kebun bunga amaryllis sangat menarik perhatian masyarakat terutama remaja untuk melakukan proses memotret diri. Demi mendapatkan hasil terbaik untuk di unggah pada jejaring sosialnya, remaja mengambil foto diri dalam keadaan tidur terlentang atau duduk ditengah taman bunga amaryllis. Hal ini berdampak pada rusaknya taman bunga amaryllis. Fenomena tersebut membuktikan bahwa remaja yang memiliki kepribadian narsistik akan melakukan berbagai cara demi mendapatkan foto terbaik sehingga individu tersebut memperoleh ketenaran pada jejaring sosial yang dimiliki.

Fenomena kecenderungan narsistik juga terjadi pada mahasiswa Fakultas Psikologi. Berdasarkan hasil wawancara yang 
dilakukan pada tanggal 13 Oktober 2017 dengan beberapa mahasiswa semester awal, mahasiswa tersebut mengatakan bahwa dalam sehari mengunggah gambar dan video di instagram sebanyak 5 sampai 10 kali. Mahasiswa mengungkapkan bahwa tujuan mengunggah gambar dan video di instagram untuk memperlihatkan aktivitas sehari-hari sehingga orang lain dapat melihat aktivitas yang dilakukan dan meminta pengguna instagram lain untuk menjadi pengikut (followers) dengan cara mempromosikan akun instagram melalui media sosial lain (seperti: BBM, Path, Facebook, dan Twitter). Selain itu, mahasiswa mengharapkan pengikut meninggalkan jejak pada setiap foto / video yang diunggah. Jejak yang diharapkan berupa tanda suka (love) atau komentar, sehingga merasa senang bila hal tersebut didapatkan.

Salah satu faktor yang mempengaruhi kecenderungan narsistik pada pengguna media sosial adalah kontrol diri (Handayani, 2014). Averill (1973) menjelaskan bahwa kontrol diri merupakan kemampuan individu untuk memodifikasi perilaku, mengelola informasi yang tidak diinginkan dengan cara menginterpretasi serta memilih tindakan berdasarkan sesuatu yang diyakini. Hurlock (2011) mengatakan bahwa kontrol diri merupakan perbedaan dalam mengelola emosi, cara mengatasi masalah, tinggi rendahnya motivasi dan kemampuan potensi dan pengembangan kompetensinya. Kontrol diri sendiri berkaitan dengan kemampuan individu dalam mengendalikan emosi serta dorongan-dorongan dalam dirinya. Lazarus (1976) mendefinisikan kontrol diri sebagai suatu kemampuan untuk menyusun, membimbing, mengatur, dan mengarahkan bentuk perilaku yang dapat membawa individu kearah konsekuensi yang positif.

Hasil penelitian yang dilakukan oleh Handayani (2014) menunjukkan bahwa peran kontrol diri cukup besar terhadap kecenderungan narsisme pada remaja. Hasil penelitian membuktikan bahwa semakin rendah kontrol diri seseorang maka semakin tinggi kecenderungan narsistik orang tersebut. Sebaliknya semakin tinggi kontrol diri seseorang maka semakin rendah kecenderungan narsistik pada orang tersebut. Hal ini sejalan dengan penelitian yang dilakukan oleh Widiana, Retnowati dan Hidayat (2004) yang menunjukkan adanya hubungan negatif antara kontrol diri dengan kecenderungan internet, sehingga individu yang mempunyai kontrol diri tinggi maka akan mampu mengarahkan dan membatasi perilaku menggunakan internet dengan memikirkan manfaat dan dampak yang ditimbulkan.

Berdasarkan konsep Averill (Ghufron \& Risnawita, 2014) terdapat 3 aspek dalam kemampuan kontrol diri, diantaranya adalah pertama kontrol perilaku (behavior control) yaitu menunjukkan kesiapan suatu respon yang secara langsung dapat mempengaruhi 
atau memodifikasi keadaan yang tidak menyenangkan. Kontrol perilaku terdiri atas dua bagian, diantaranya adalah kemampuan mengatur pelaksanaan (regulated administration), yaitu kemampuan individu menentukan siapa yang mengendalikan situasi atau keadaan yaitu dirinya atau orang lain dan kemampuan memodifikasi stimulus (stimulus modifiability), yaitu kemampuan individu mengetahui cara dan waktu menghadapi stimulus yang tidak dikehendaki. Stimulus dapat dihadapi dengan menggunakan beberapa cara, diantaranya adalah mencegah atau menjauhi stimulus, menempatkan tenggang waktu diantara rangkaian stimulus yang sedang berlangsung, dan menghentikan stimulus sebelum waktunya berakhir serta membatasi intensitasnya.

Kedua, kontrol kognitif (cognitive control) yaitu menunjukkan kemampuan individu mengolah informasi yang tidak dikehendaki dengan cara menginterpretasi, menilai, atau menghubungkan suatu kejadian dalam kerangka kognitif sebagai adaptasi psikologis. Ketiga, kontrol keputusan (decisional control), yaitu kemampuan untuk memilih suatu tindakan berdasarkan sesuatu yang individu yakini atau setujui.

Faktor lain yang mempengaruhi kecenderungan narsistik salah satunya adalah harga diri. Karakteristik remaja dengan kepribadian narsistik memiliki karakteristik yang sebenarnya merupakan sebagai topeng bagi harga dirinya yang rapuh Davison, Neale dan Kring, (2010). Remaja menginginkan penghormatan dan perhatian dari orang lain demi meningkatkan harga diri yang dimilikinya. Terjadinya kecenderungan narsistik menurut Nemiah (2007) pada umumnya karena kegagalan yang mengakibatkan perasaan tidak berdaya dan menderita sehingga mengakibatkan perasaan harga diri yang rendah dan depresi. Tiap-tiap individu memiliki tingkat harga diri yang bervariasi. Keinginan untuk menganggap bahwa dirinya berharga, seseorang harus merasakan bahwa dirinya dicintai oleh orang lain, dirinya kuat atau baik dan rasa saling memiliki. Keyakinan bahwa dirinya tidak dicintai, bergantung pada orang lain, sehingga mengakibatkan rasa kehilangan harga diri dan depresi.

Hasil penelitian yang dilakukan oleh Adi \& Yudiati (2009) bahwa narsistik pada pengguna friendster dapat dipengaruhi oleh tingkat harga diri, hasil penelitian tersebut membuktikan bahwa semakin rendah harga diri seseorang maka semakin tinggi kecenderungan narsistik orang tersebut, sebaliknya semakin tinggi harga diri seseorang maka semakin rendah kecenderungan narsistik pada orang tersebut. Selaras dengan hasil penelitian Valkenburg (2006) bahwa penggunaan jejaring sosial akan mempengaruhi harga diri remaja. Harga diri pengguna jejaring sosial akan lebih mudah terpengaruh apabila 
digunakan untuk berkomunikasi daripada hanya mencari informasi saja. Mehdizadeh (2010) berpendapat bahwa individu yang menghabiskan banyak waktu untuk online memiliki harga diri yang rendah dan mereka mencoba untuk meningkatkan interaksi sosial dengan pengguna lainnya untuk meningkatkan harga dirinya.

Menurut Coopersmith (Lestari \& Koentjoro, 2002) mengatakan bahwa harga diri merupakan hasil evaluasi individu terhadap dirinya sendiri yang diekspresikan dalam sikap terhadap diri sendiri. Evaluasi ini menyatakan suatu sikap penerimaan atau penolakan dan menunjukkan seberapa besar individu percaya bahwa dirinya mampu, berarti, berhasil, berharga menurut standar dan nilai pribadinya. Harga diri adalah gagasan mengenai diri secara global yang mengacu pada keseluruhan evaluasi diri sebagai individu, atau bagaimana orang merasakan mengenai diri mereka sendiri dalam arti yang komprehensif (Verkuyten, 2005). Baron dan Byrne (2012) juga berpendapat bahwa harga diri adalah evaluasi diri yang dibuat oleh setiap individu, sikap orang terhadap dirinya sendiri dalam rentang dimensi positif sampai negatif. Coopersmith (Andarini, Susandari, \& Rosiana, 2012) mengemukakan 4 aspek dalam harga diri, yaitu:

Power (Kekuasaan), yaitu kemampuan untuk mempengaruhi dan mengontrol orang lain beserta dirinya sendiri. Pada situasi tertentu kebutuhan ini ditunjukkan dengan penghargaan dan penghormatan dari orang lain. Aspek ini dapat berupa pengaruh dan wibawa pada seorang individu. Ciri-ciri individu yang mempunyai aspek ini biasanya menunjukkan sikap asertif. Significant (Keberartian), yang merupakan keberartian individu dalam lingkungan. Individu akan merasa berarti jika ada penghargaan, penerimaan, perhatian, dan kasih sayang dari orang-orang terdekat seperti keluarga, sahabat, atau masyarakat. Dengan adanya lingkungan yang mendukung, menerima, dan menghargai akan membuat individu semakin berarti yang akhirnya membentuk harga diri yang positif. Sebaliknya, jika lingkungan tidak atau jarang memberikan stimulus positif yang berupa penerimaan, penghargaan atau dukungan kepada seorang individu, maka ia akan merasa ditolak dan kemudian mengucilkan diri.

Virtue (Kebajikan), yaitu ketaatan pada nilai moral, etika, dan aturan-aturan yang ada dalam masyarakat. Seorang yang taat pada aturan-aturan dan ketentuan yang ada dalam masyarakat akan mempunyai perasaan berharga dan bangga pada diri sendiri. Hal ini disebabkan bahwa dengan menunjukkan perilaku yang diharapkan dan diinginkan oleh masyarakat, maka orang lain akan menghargai dan menghormati individu yag bersangkutan sebagai orang yang berkelakuan baik dan bisa dijadikan teladan. Hal ini akan mendorong terbentuknya harga 
diri yang positif, demikian juga sebaliknya. Aspek ini ditunjukkan dengan bagaimana individu melihat persoalan benar atau salah berdasarkan moral, norma dan etika yang berlaku dalam lingkungan interaksinya.

Competence (Kemampuan), yaitu kemampuan untuk mencapai apa yang dicitacitakan atau diharapkan. Hal ini berhubungan dengan kemampuan yang dimiliki individu, dengan adanya kemampuan yang cukup individu merasa yakin untuk mencapai apa yang dicita-citakan dan mampu mengatasi setiap masalah yang dihadapinya. Aspek ini didukung oleh pengalaman tentang kesuksesan yang pernah diraih seorang yang membuat individu yakin dan mampu menghadapi setiap masalah, sedangkan pengalaman masa lalu yang penuh dengan kegagalan akan membuat individu bermasalah dengan harga dirinya.

Berdasarkan uraian di atas dapat disimpulkan bahwa kecenderungan kepribadian narsistik adalah kecenderungan kepribadian yang memiliki ciri dari gangguan kepribadian narsistik antara lain meningkatnya rasa kebesaran diri yang unik dalam fantasia atau perilaku, kebutuhan untuk dikagumi, dan cinta diri yang berlebihan, merasa diri penting secara berlebihan, keinginan untuk diperhatikan dan perlakuan istimewa dari orang lain, serta kurangnya empati sehingga kurang mampu memahami dan merasakan perasaan orang lain, serta munculnya rasa keinginan diri untuk mengeksploitasi dengan cara memanfaatkan orang lain demi tercapainya ambisi pribadi, meskipun mengorbankan kepentingan orang lain. Berdasarkan dari beberapa uraian di atas maka dapat ditegaskan bahwa yang dimaksud kontrol diri dalam bentuk penelitian ini adalah kemampuan seseorang untuk menahan keinginan dan mengendalikan tingkah lakunya sendiri, mampu mengendalikan emosi serta dorongan dorongan dari dalam dirinya yang berhubungan dengan orang lain, lingkungan, pengalaman dalam bentuk fisik maupun psikologis untuk memperoleh tujuan di masa depan dan dinilai secara sosial.

Berdasarkan fenomena yang terjadi maka penulis ingin melakukan penelitian untuk mengetahui hubungan antara kontrol diri dan harga diri dengan kecenderungan narsistik pada mahasiswa semester awal.

\section{Metode}

\section{Subjek penelitian}

Populasi yang digunakan dalam penelitian ini adalah mahasiswa semester awal dengan Program Studi Psikologi. Kriteria karakteristik dalam penelitian ini adalah mahasiswa psikologi semester awal yang berusia 18 - 22 tahun, menggunakan media sosial instagram, mengunggah foto atau video sebanyak > 5 kali dalam sehari. Subjek berjumlah 54 orang. 


\section{Metode pengumpulan data}

Skala yang digunakan dalam penelitian ini adalah skala kecenderungan narsistik, skala kontrol diri dan skala harga diri. Aitem-aitem dari ketiga skala ini menggunakan metode Likert dengan empat alternatif jawaban, yaitu Sangat Sesuai (SS) dengan skor empat untuk aitem favorable dan skor satu untuk aitem unfavorable; Sesuai (S) diberi skor tiga untuk aitem favorable dan skor dua untuk aitem unfavorable; Tidak Sesuai (TS) diberi skor dua untuk aitem favorable dan skor tiga untuk aitem unfavorable; Sangat Tidak Sesuai (STS) diberi skor satu untuk aitem favorable dan skor empat untuk aitem unfavorable.

Pertama, skala kecenderungan narsistik yang digunakan dalam penelitian ini mengambil skala yang disusun oleh Suhartanti (2016) dan telah dimodifikasi oleh peneliti sehingga dapat disesuaikan dengan subjek yang akan diambil yaitu mahasiswa semester awal. Skala yang digunakan adalah ciri-ciri kepribadian narsistik yang terdapat dalam DSM V (2013) yang berisi 32 aitem. Kedua, skala kontrol diri yang berisi 24 aitem. Skala yang akan digunakan dalam penelitian ini peneliti membuat sendiri skala berdasarkan teori kontrol diri yang dikemukakan oleh Averill (Ghufron \& Risnawita, 2014). Ketiga, skala harga diri yang terdiri dari 32 aitem yng disusun berdasarkan 4 aspek harga diri, yaitu power, signifivance, virtue, competence.

\section{Teknik analisis data}

Metode analisis data yang dilakukan oleh peneliti adalah metode statistik parametrik dengan teknik analisis Regresi Linier Berganda (Multiple Linier Regression). Selain itu, dilakukan uji hipotesis yang dilakukan dengan analisis korelasi. Data-data tersebut diolah dengan komputer menggunakan program Statistical Package and Social Science (SPSS) 16.0 for Windows.

\section{Hasil}

\section{Hasil uji normalitas}

Pengujian normalitas menggunakan teknik statistik one sample kalmogrov-smimov test dari program SPSS 16.0 for windows. Kaidah yang digunakan adalah jika $\mathrm{p}>0.05$ maka sebarannya dinyatakan normal dan sebaliknya jika $\mathrm{p}<0.05$ maka sebarannya dinyatakan tidak normal.

Tabel 1. Hasil Uji Normalitas Sebaran Aitem

\begin{tabular}{cccccc}
\hline Variabel & Skor KS-Z & Mean & SD & p & Keterangan \\
\hline Narsistik & 0.837 & 43.94 & 5.832 & 0.485 & Normal \\
Kontrol Diri & 0.756 & 37.77 & 4.205 & 0.618 & Normal \\
Harga Diri & 0.777 & 57.98 & 6.527 & 0.777 & Normal \\
\hline
\end{tabular}


Berdasarkan hasil analisis uji coba normalitas yang tertera pada tabel, diketahui bahwa variabel kecenderungan narsistik dengan nilai mean a sebesar 43.94 dan standar deviasi sebesar 5.832 memiliki nilai $\mathrm{K}-\mathrm{Z}=0.837$ dan $\mathrm{p}=0.485$. Pada variabel kontrol diri dengan mean 37.77 dan standar deviasi 4.205 memiliki nilai $\mathrm{K}-\mathrm{Z}=0.756$ dan $\mathrm{p}=0.756$. Pada variabel nilai toleransi mendekati 1 sehingga dapat dikatakan tidak terjadi multikolinieritas.

\section{Hasil uji hipotesis}

Analisis regresi yang diperoleh dalam penelitian ini antara ketiga variabel tersebut sebesar $\mathrm{R}=0.535$ dengan nilai signifikansi sebesar $p=0.000(p<0.01)$, serta nilai $\mathrm{F}$ hitung

Tabel 2. Uji Multikolinieritas

\begin{tabular}{cccc}
\hline Variabel & Toleransi & Nilai VIF & Keterangan \\
\hline Kontrol Diri & 0.576 & 1.735 & Tidak terjadi multikolinieritas \\
Harga Diri & 0.576 & 1.735 & Tidak terjadi multikolinieritas \\
\hline
\end{tabular}

harga diri dengan mean 57.98 dan standar deviasi 6.527 memiliki nilai $\mathrm{K}-\mathrm{Z}=0.777$ dan $\mathrm{p}=$ 0.777 , sehingga variabel yang diteliti memiliki sebaran normal.

\section{Hasil uji multikolinieritas}

Uji multikolinieritas digunakan untuk membuktikan atau menguji ada tidaknya hubungan yang linier antara variabel bebas, pada analisis regresi linier berganda disyaratkan bahwa antara variabel bebas tidak boleh terjadi hubungan yang sempurna (multikolinieritas). Bilfarsah (Setiawan, 2016) menyebutkan bahwa kriteria yang digunakan adalah nilai VIF kurang dari 10 dan nilai toleransi lebih dari 0.1, maka tidak terdapat hubungan yang multikolinieritas.

Berdasarkan tabel 2 dapat diketahui bahwa pada variabel persepsi kontrol diri dan harga diri diketahui nilai VIF sebesar 1.735 dan pada tabel anova sebesar 10.040 (F hitung > F tabel $=4.74$ ).

\section{Pembahasan}

Hasil analisis menunjukkan ada hubungan negatif yang signifikan antara kontrol diri dan harga diri dengan kencenderungan narsistik pada mahasiswa semester awal. Semakin tinggi kontrol diri maka akan semakin rendah kecenderungan narsistik. Sebaliknya semakin tinggi harga diri maka akan semakin rendah kecenderungan narsistik.

Berdasarkan hasil analisis korelasi dengan tidak mengontrol variabel harga diri.diperoleh skor koefisien korelasi sebesar 0,433 dengan nilai signifikansi $p=0.001(p<$ 0.01). Hal ini menunjukkan bahwa ada hubungan negatif yang sangat signifikan antara kontrol diri dengan kecenderungan narsistik. Hasil analisis korelasi selanjutnya antara variabel harga diri dengan tidak mengontrol 
variabel kontrol diri, diperoleh skor koefisien korelasi sebesar $-0,521$ dengan nilai signifikansi $p=0.000(p<0.01)$. Hal ini menunjukkan bahwa ada hubungan negatif yang sangat signifikan antara harga diri dengan kecenderungan narsisitik. Selain itu, berdasarkan kategori ketiga variabel penelitian yaitu kontrol diri dalam kategori tinggi yaitu 37 orang (69.81\%) dan $16(30.19 \%)$ orang dengan kategori sedang. Kemudian variabel harga diri dalam kategori tinggi yaitu 42 orang (79.25\%) dan 11 (20.75\%) dengan kategori sedang. Variabel kecenderungan narsistik berada dalam kategori rendah yaitu 28 orang (52.83\%) dan 25 (47.17\%) orang dengan kategori sedang.

Penelitian ini sejalan dengan penelitian Suhartanti (2016) yang menyatakan bahwa ada hubungan antara kontrol diri dengan perilaku narsistik pada pengguna jejaring sosial instagram. Hasil penelitian tersebut menunjukkan bahwa ada hubungan yang signifikan antara kontrol diri dengan narsisme pada remaja. Penelitian lain yang mendukung hasil uji hipotesis pada penelitian ini dilakukan oleh Handayani (2014), yang menyatakan bahwa salah satu faktor yang mempengaruhi narsisme pada individu adalah kontrol diri. Hasil penelitian menunjukkan bahwa terdapat hubungan negatif antara kontrol diri dengan narsisme, dengan sumbangan efektif sebesar 49.8\%. Dariyo (2004) mengatakan individu yang memiliki kontrol diri baik dalam memanfaatkan facebook, yaitu individu mampu mengontrol perilaku aktif menggunakan jejaring sosial, berusaha untuk mengontrol diri dalam menggunggah status atau foto, mampu mengendalikan pikiran-pikiran yang membuatnya justru tertekan dan mampu membuat pilihan-pilihan alternatif dalam hidupnya.

Hasil penelitian Santi dan Damariswara (2017) menunjukkan bahwa self esteem berhubungan dengan kecenderungan narsisme pada mahasiswa pengguna facebook. Semakin rendah harga dirinya berarti semakin narsis pada pengguna facebook. Sebaliknya semakin tinggi harga dirinya maka semakin rendah narsisnya di facebook. Kegiatan narsisme sering dilakukan dengan menampilkan gambar glamor, promosi diri sendiri-baik melalui foto maupun tulisan. Biasanya individu sangat narsisme bila sering menunjukkan foto mereka yang diambil sendiri dalam situasi apa pun.

\section{Simpulan}

Berdasarkan hasil penelitian dapat disimpulkan bahwa terdapat hubungan negatif antara kontrol diri dan harga diri dengan kecenderungan narsistik pada mahasiswa semester awal pengguna instagram. Semakin tinggi kontrol diri dan harga diri pada mahasiswa maka kecenderungan narsistik semakin rendah, sebaliknya semakin rendah kontrol diri dan harga diri pada mahasiswa maka kecenderungan narsistik semakin tinggi. Kedua, terdapat hubungan negatif kontrol diri terhadap kecenderungan narsistik pada 
mahasiswa semester awal, artinya semakin tinggi kontrol diri mahasiswa maka kecenderungan narsistik rendah. Demikian sebaliknya semakin rendah kontrol diri maka semakin tinggi kecenderungan narsistik yang dimiliki mahasiswa semester awal. Ketiga, terdapat hubungan negatif antara harga diri terhadap kecenderungan narsistik pada mahasiswa semester awal, semakin tinggi harga diri yang dimiliki mahasiswa semester awal maka semakin rendah kecenderungan narsistik pada mahasiswa semester awal. Demikian sebaliknya semakin rendah harga diri maka semakin tinggi kecenderungan narsistik yang dimiliki mahasiswa semester awal.

Kontrol diri dan harga diri secara bersama-sama memberikan sumbangan efektif sebesar $28.7 \%$ terhadap kecenderungan narsistik, sedangkan sisanya dipengaruhi oleh variabel lain. Hal ini berarti bahwa variabel bebas yakni kontrol diri dan harga diri secara simultan maupun tanpa mengontrol salah satu variabel bebas berkorelasi terhadap variabel terikat, yakni kecenderungan narsistik. Kontrol diri dan harga diri yang tinggi mempunyai peran yang penting dalam mempengaruhi kecenderungan narsistik pada mahasiswa semester awal.

\section{Saran}

Berdasarkan hasil penelitian, pembahasan, dan kesimpulan, maka penulis akan memberikan saran yang diharapkan dapat bermanfaat bagi pihak lain, antara lain bagi mahasiswa diharapkan dapat meningkatkan kontrol diri maupun harga diri dengan baik dalam menggunakan jejaring sosial instagram agar mengurangi kecenderungan narsistik. Mahasiswa juga harus mampu untuk mengembangkan citra diri dengan cara yang positif tanpa harus mengikuti arus kemajuan teknologi yang kurang baik.

Bagi peneliti selanjutnya hendaknya dapat melakukan penelitian dengan faktor lain yang berpengaruh terhadap kecenderungan narsistik. Selain itu bagi peneliti selanjutnya diharapkan dapat melakukan pada kategori subjek yang berbeda selain mahasiswa semester awal. Peneliti selanjutnya dapat mengembangkan alat ukur penelitian, untuk mendapatkan reliabilitas dan validitas alat ukur yang lebih tinggi yang digunakan dalam penelitian ini. Metode yang digunakan perlu diperluas dengan menggunakan metode lain seperti menggunakan metode wawancara kepada subjek yang memiliki kecenderungan narsistik maupun dengan metode eksperimen.

\section{Daftar Pustaka}

Adi, P. S., \& Yudiati, M. E. A. (2009). Harga diri dan kecenderungan narsisme pada pengguna friendster. Jurnal Ilmiah Psikologi, 3(1), 25-32..

Andarini, S., Susandari, S., \& Rosiana, D. (2012). Hubungan antara "self esteem" dengan derajat stres pada siswa Akselerasi SDN Banjarsari 1 Bandung. Prosiding SNaPP: Sosial, Ekonomi dan Humaniora, 3(1), 217 224. 
Asosiasi Penyelenggara Jasa Internet Indonesia [APJII]. (2016). Profil Pengguna Internet Indonesia. Diakses 17 Oktober 2017, dari Asosiasi Penyelenggara Jasa Internet: https://apjii.orid/content/read/39/264/S urvei-Internet-APJII-2016.

Averill, J. R. (1973). Personal control over aversive stimuli and its relationship to stress. Psychological bulletin, 80(4), 286.

Baron, R. A., \& Byrne. D. (2012). Psikologi Sosial jilid 2. Jakarta: Erlangga.

Calhoun, J. F., Acocella, J. R., 1995. Psychology of Adjustment and Human Relationship. New York: McGraw Hill, Inc.

Dariyo, A. (2004). Psikologi Perkembangan Remaja. Bogor: Ghalia Indonesia.

DSM-V. (2013). The Diagnostic and Statistical Manual of Mental Disorder Fifth Edition. Washington DC: American Psychiatric Publishing.

Davison, G. C., Neale, J. M. \& Kring, A. M. (2010). Psikologi Abnormal Edisi Kesembilan. (Alih Bahasa: Noermalasari Fajar). Jakarta: Rajawali Press.

Handayani, N. (2014). Hubungan antara kontrol diri dengan narsisme pada remaja pengguna facebook. Disertasi, Universitas Muhammadiyah Surakarta, Surakarta.

Hurlock, E. B. (2011). Psikologi Perkembangan Suatu Pendekatan Sepanjang Rentang Kehidupan, Edisi 5. Jakarta: Erlangga.

Lazarus, R. S. (1976). Pattern of Adjustment (Third Edition). New York: Mc Graw Hill Inc.

Lestari, R., \& Koentjoro, K. (2002). Pelatihan berpikir optimis untuk meningkatkan harga diri pelacur yang tinggal di pantai dan luar pantai sosial.Jurnal Ilmiah Berkala Psikologi Indigenous, 6(2), 134-146.

Ghufron, M. M., \& Risnawita, R. S. (2014). TeoriTeori Psikologi. Yogyakarta: Ar-Ruzz Media.

Mehdizadeh, S. (2010). Self-presentation 2.0: Narcissism and self esteem on Facebook. Cyberpsychology, behavior, and social networking, 13(4), 357-364.

Nemiah. (2007). Narsisme, kagum kok pada diri sendiri. Diunduh pada 13 Oktober 2017, dari: http://www.gayahidupsehatonline.com.

Nevid, J. S., Rathus, S. A., \& Greene, B. (2005). Psikologi Abnormal. Edisi Kelima Jilid 1. Alih Bahasa: Tim Fakultas Universitas Indonesia. Jakarta: Erlangga.

Nistanto, R. K. (2015, November 30). Demi Selfie Semata, Kebun Bunga "Amaryllis" Merana. Kompas.

Ojanen, T., Findley, D., \& Fuller, S. (2012). Physical and relational aggression in early adolescence: Associations with narcissism, temperament, and social goals. Aggressive Behavior, 38(2), 99-107.

Safitri, R. M., Ambarwati, Y. (2011). Hubungan antara kepribadian narsistik dengan perilaku konsumtif pada remaja di Yogyakarta. Jurnal Sosiohumaniora, 2(2), 53-60.

Santi, N. N., \& Damariswara, R. (2017). Hubungan antara self esteem dengan self disclosure pada saat chatting di facebook. Pedagogia: Jurnal Pendidikan, 6(1), 110114.

Santrock, J. W. (2012). Life Span Development (13 th Edition). New York: Mc Graw-Hill.

Suhartanti, L. (2016). Pengaruh Kontrol Diri 
Terhadap Narcisstic Personality Disorder Pada Pengguna Jejaring Sosial Instagram di SMAN 1 Seyegan. Skripsi (Tidak Diterbitkan), Universitas Negeri Yogyakarta, Yogyakarta.

Sugiyono. (2008). Metode Penelitian Kuantitatif, Kualitatif dan R\&D. Bandung: Penerbit Alf.

Suryanto, T. L. M., Puteri, H. A., \& Pratama, A. (2019). Eksplorasi teori gratifikasi untuk layanan jejaring sosial: Studi kasus sikap pengguna terhadap Instagram di Indonesia. Indonesian Journal of Information Systems, 1(2), 108-118.

Suryanto. (2010, April 26). Mahasiswa AS kecanduan internet. Diunduh pada 13 $0 \mathrm{k} \mathrm{t} \mathrm{o} \mathrm{b} \mathrm{e} \mathrm{r} 2017, \quad \mathrm{~d}$ a r i : http://www.antaranews.com/berita/1842 67/mahasiswa-as-kecanduan-internet.

Valkenburg, P. M., Peter, J., \& Schouten, A. P. (2006). Friend networking sites and their relationship to adolescents' well-being and social self-esteem. CyberPsychology \& Behavior, 9(5), 584-590.

Verkuyten. (2005). Konsep identitas sosial. Diunduh pada 21 Oktober 2017, dari: https://www.academia.edu/9347778/Ko ntruksi_identitas_kultural_remaja_nomad en/.

Weiser, E. B. (2015). \# Me: Narcissism and its facets as predictors of selfie-posting frequency. Personality and Individual Differences, 86, 477-481.

Widiana, H., S., Retnowati, S., Hidayat, R. (2004). Kontrol diri dan kecenderungan kecanduan internet. Humanitas: Indonesian Psychologycal Journal, 1(1), 616.

Widianti, R. (2013). Apa kata Psikolog Soal Foto Narsis di Jejaring Sosial? [Online]. Kompas.
Diunduh pada 17 Oktober 2017, dari: http://health.kompas.com/read/2013/12 /18/1151301/Apa.

Wiramihardja, S. A. (2015). Pengantar Psikologi Abnormal (edisi revisi). Bandung: Refika Aditama. 